\title{
Motivation of Parents Towards Reading Multilingual eBooks To Pre-School Children
}

\author{
https://doi.org/10.3991/ijim.v13i01.9060 \\ Kwee Teck See $(\bowtie)$ \\ Tunku Abdul Rahman University College, Malaysia \\ seektetarc.edu.my \\ Bava Harji Madhubala, Ah Choo Koo \\ Multimedia University, Malaysia
}

\begin{abstract}
The use of mobile devices for language learning, within Mobile Assisted Language Learning (MALL), has been found to motivate children to read digital print. However, parents need to be convinced of the benefits of this new technology-assisted learning method within a multilingual learning context. A case study was conducted to propose a MALL framework in which teachers and parents created a shared meaningful learning environment to develop young children's emergent multilingual literacy skills, using mobile devices installed with interactive multilingual eBooks. This paper reports the findings, specifically on the parents' attitude and motivation towards reading multilingual eBooks with their children. A group of 25 multi-ethnic families, together with their 5-year-old children participated in this study. A mixed-method explanatory research design obtained data on parent's attitude and motivation from a questionnaire, interview, and feedback form. The results show a high level of parents' acceptance toward reading eBooks with their children. Parents attributed their positive attitude and motivation towards MALL to the use of the multimedia, multilingual, and mobile platform. The MALL framework was also found to encourage parents and other adults to scaffold the children's multilingual skills development. However, some parents expressed a stronger preference for printed books and were concerned with health issues associated with the children's use of eBooks. Areas for improvements and future research are also made in this paper.
\end{abstract}

Keywords-Mobile learning, school-home cooperation, multilingual, eBook

\section{Introduction}

Research evidence has established positive links between home literacy practices and children's language and literacy skills [1] [2]. Mobile-assisted Language Learning (MALL) that places emphasis on the mobility of learning appears to be an ideal model to form a link between schools and homes, making the development of children's emergent multilingual literacy skills a joint effort. Applications of MALL show positive impact on children' achievement, interests, and motivation [3], however, parents need to be convinced of the benefits of this technology-assisted learning method [4]. There was 
a call to update the current data on acceptability of different technology-assisted intervention components to different groups of parents [5]. There is also an absence of studies that examine aspects of early emergent literacy and tablets in the home context [6]. As the impact of tablets on early emergent literacy is not yet fully known, two important considerations are the quality of emergent literacy apps and the importance of scaffolding young children's use of tablet at home and preschool to support emergent literacy development [7]. Hence, the use of tablets to support emergent literacy development through parental scaffolding in an informal setting is a promising area of inquiry. Although there are numerous MALL studies on bilingual literacy skills development, none address the challenges of developing early emergent multilingual literacy, especially among young learners. Meanwhile, there are challenges that MALL has yet to answer in terms of (1) parent acceptance of the emergent literacy app and tablets within home context, (2) use of multimedia in emergent literacy app, and (3) a framework that forms a partnership between schools and homes to develop early emergent multilingual literacy skills.

\section{Literature Review}

Since the 90s', research evidence highlights that reading storybooks is an effective avenue to lead children into the world of literacy [8]. Reading storybooks at home in the children's first language can support literacy development of a second language [9]. Therefore, it is crucial that the acquisition of children's first language is well supported in order to promote the development of multiple second languages. Other studies have also provided evidence for parents' positive attitude towards reading storybooks and towards being involved in their children's early emergent second language literacy skills development [10] [11]. Hence, to effectively develop early emergent literacy skills among young learners, storybook reading with parental involvement is a viable avenue.

Most parents have indicated that they prefer conventional printed books because books are highly portable and there is no reliance on battery power [4]. Albeit some parents maintain that their children prefer reading using printed books compared to eBooks [12], the use of touchscreen tablets among young children is undeniably increasing in homes [7] and more parents acknowledge the positive effects of mobile devices on children's motivation towards digital reading [13]. With frequent exposure to digital print in homes, children are found to be more likely to read on screens than on paper outside the school and are more likely to say that they prefer to read on screen than on paper [14]. Despite differences in preference among parents and children on the choice of the reading media, there is an increase in acceptance of digital print reading in the home environment because touchscreen devices have features that enhance learning, such as interactive media and rich in contents that support individual needs [15].

Mayer's Cognitive Theory of Multimedia Learning indicates that multimedia presentation could be an effective means of engaging children because they use audi- 
tory and visual channels in the learning process [16]. The use of multimedia presentation in educational technology increases children's motivation and reading engagement [17], helps them to form links between the media, assists in navigating through difficult texts [18], and facilitates story comprehension [19]. However, multimedia and interactive features that most typical enhanced eBooks provide resulted in young learners' difficulty in retaining attention on tasks and are distracted from the story content [20]. A study found that parents were engaged in more distractive talk with their children about the enhanced eBook format and environment compared to paper-based book [21]. The increased engagement in enhanced eBooks did not translate into better emergent literacy skills [22] and poorly integrated multimedia components lead to cognitive overload on young children [19]. These findings suggested that eBooks should allow distractive multimedia features such as background music and animations to be muted. Although multimedia and mobile devices combined motivate young learners to read on screen, it is the level of parental involvement that determines the educational value of eBook reading. Research indicated that children display higher levels of learning persistence within an adult led eBook reading setting [23]. Another study also found that reading eBook results in more child-initiated communication, however, lower story recall without adult scaffolding [24].

MALL has been found to improve students' native language learning [25] and second language [26]. Mobile eBooks are found to aid in developing pre-schoolers' emergent literacy skills and therefore educators are encouraged to consider incorporating eBooks reading activities into formal education [27]. Mobile devices offer an educational potential for emergent literacy learners because of its accessibility, mobility, and navigational touchscreen interface, however, there are three major challenges of MALL in promoting emergent literacy: social, theoretical, and technological [28]. In terms of social challenges, parents have expressed their concerns about the screen-time children spend on mobile devices that could have a negative impact on children's social, sensorimotor, and self-regulation skills. The second challenge is the lack of theory and framework with which researchers and developers could use to guide the design of mobile device apps for young children. The third challenge is the technical difficulties associated with the use of tablets for educational purposes. Young children, who are emerging digital natives, depend on parents' guidance on the operation of mobile devices.

\section{The MALL framework}

A case study was conducted to establish a MALL framework that forms a partnership between a school and homes within a "shared meaningful learning environment", using mobile devices installed with an interactive multilingual storybook as a tool (see Figure 1). In the context of this study, children refer to pre-schoolers, adults refer to parents, siblings, or anyone who are more capable. Multilingual is limited to Malay, English, and Chinese languages that are taught in the school where this study was conducted. The MALL framework is based on the sociocultural theory in which Vygotsky placed 
emphasis on the importance of social interaction between adults and children in learning a language [29]. Vygotsky stated that a child first does things in a social context with the assistance of more capable adults or peers, and gradually progresses from dependence on others to independent action and thinking [30]. Inspired by Vygotsky's concept of the zone of proximal development (ZPD), the concept of scaffolding, is an idea closely related to social learning [31]. In the context of second language learning, adults scaffolding children within the ZPD would enable multilingual acquisition over time. Adult support will gradually reduce as the children's multilingual literacy develops.

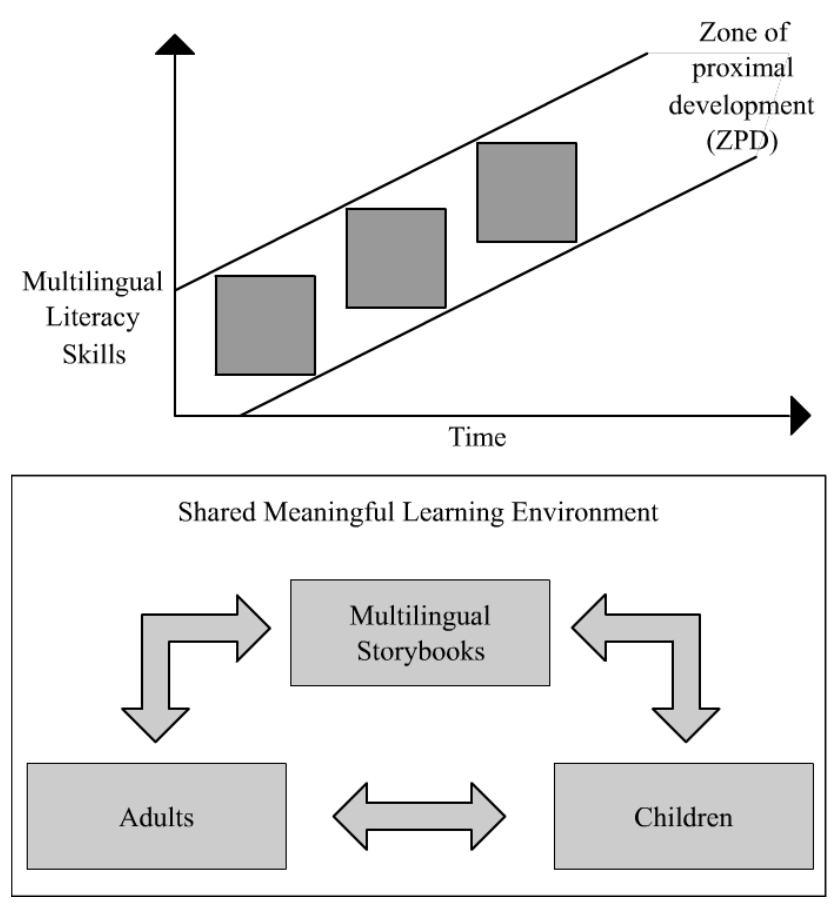

Fig. 1. Mobile Assisted Language Learning framework (Adapted from [11])

Mobile devices provide a distinct opportunity for collaboration between schools and homes in a shared meaningful learning environment (see Figure 2). There are five core processes in this form of collaboration under the proposed MALL framework. First, in school, teachers create multilingual storybooks, formatted as eBooks, and use mobile devices as a means to disseminate eBooks to children. Second, at homes, young children read multilingual eBooks, scaffolded by more capable adults. Third, upon completion of each reading session, both the children and adults record their feedback on the shared reading experience, using a mobile device. Fourth, in school, educators retrieve feedback and reading records from mobile devices returned by children or parents. Fifth, educators perform data analysis, with which they will identify how children 
and parents respond to the eBooks. Information generated from data analysis is translated into content analysis and design, which educators design new contents to meet children and parents' needs, reading interests and preferences. A new cycle starts with new multilingual contents distributed to children and parents.

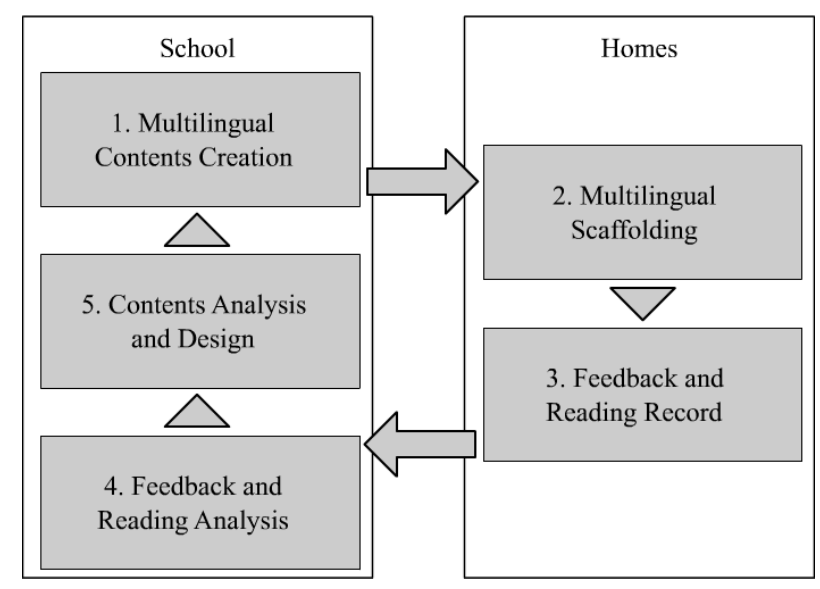

Fig. 2. Model of a shared meaningful learning environment

The objective of this research was to explore the MALL framework, in improving the design of an emergent multilingual literacy app, named Multilingual Mobile Storybook Reader (MMSR), and examining how it affects parents' attitude and motivation toward scaffolding young children's early emergent multilingual literacy development, through the use of mobile devices at home, with the support of the school. This paper presents evidence for the value of MALL with multilingual eBooks reading as a means to motivate adults in developing young children's early emergent multilingual literacy. The research questions addressed in this paper are:

- What are the parents' levels of acceptance of MALL?

- To what extent does MALL affect the parents' attitude and motivation towards reading to their children in multiple languages?

\section{Methods and Materials}

\subsection{Participants}

A group of 25 multi-ethnic families, together with their 5-year-old children from a preschool located in Melaka, Malaysia participated in this study. The preschool uses English as the medium of instruction, and Malay and Chinese are taught as subjects to all the children. A project committee consisting of researchers, school principal, and two school teachers was formed. The composition of the parents' ethnic groups is presented in Table 1. 
Table 1. Parents' ethnic group

\begin{tabular}{|l|l|}
\hline \multicolumn{1}{|c|}{ Ethnicity } & \multicolumn{1}{c|}{ No. (\%) } \\
\hline Malay & $12(48.0)$ \\
\hline Indian & $9(36.0)$ \\
\hline Chinese & $4(16.0)$ \\
\hline Total & $25(100)$ \\
\hline
\end{tabular}

As seen in Table 2, the majority of the parents, regardless of their ethnicity, are confident of their proficiency in the Malay language; 80 per cent of the parents rated themselves as "Good" and above in all four language skills, i.e. speaking, listening, reading and writing. However, parents were less confident in their proficiency in the English language compared to the Malay language. Less than half of the parents rated themselves "Good" in all four skills. A large majority of parents rated themselves as "Poor" or below in all Chinese language skills.

Table 2. Parents' multilingual skills

\begin{tabular}{|c|c|c|c|c|c|c|}
\hline \multirow[t]{2}{*}{ Language } & \multirow[t]{2}{*}{ Skills } & Very Good & Good & Moderate & Poor & Very Poor \\
\hline & & No. \% & No. (\%) & No. (\%) & No. (\%) & No. (\%) \\
\hline \multirow[t]{2}{*}{ Malay } & Speaking and Listening & $14(56.0)$ & $6(24.0)$ & $4(16.0)$ & $1(4.0)$ & $0(0.0)$ \\
\hline & Reading and Writing & $15(60.0)$ & $5(20.0)$ & $5(20.0)$ & $0(0.0)$ & $0(0.0)$ \\
\hline \multirow[t]{2}{*}{ English } & Speaking and Listening & $5(20.0)$ & $4(16.0)$ & $14(56.0)$ & $1(4.0)$ & $1(4.0)$ \\
\hline & Reading and Writing & $5(20.0)$ & $6(24.0)$ & $12(48.0)$ & $1(4.0)$ & $1(4.0)$ \\
\hline \multirow[t]{2}{*}{ Chinese } & Speaking and Listening & $2(8.0)$ & $1(4.0)$ & $0(0.0)$ & $2(8.0)$ & $20(80.0)$ \\
\hline & Reading and Writing & $3(12.0)$ & $0(0.0)$ & $0(0.0)$ & $2(8.0)$ & $20(80.0)$ \\
\hline
\end{tabular}

$(\mathrm{n}=25)$

\subsection{Procedures and Methods}

The project duration was 21 weeks. Upon briefing, the school principal and teachers consented to participate in this study. Permission to participate and parental consent was also obtained prior to the project. Subsequently, the project committee members, parents, and children were briefed on the features of MMSR. Each participating family received a 6-inch tablet containing MMSR and multilingual eBooks. Tablets were distributed from the beginning of the project and were collected once a week for the installation of new stories and data collection purposes.

Three data collection methods were adopted: 1) interview of parents and 2) questionnaire were administrated towards the end of the study, and 3) feedback form programmed into the MMSR and data was collected on a weekly basis. Open-ended interviews aimed at gathering parents' views of MALL as well as their attitude and motivation toward reading in multiple languages to their children. A self-designed questionnaire comprising 6 items, using the Likert's Scale 5 format, measured parents' attitude and motivation was also administrated to identify their views on MMSR as a multilingual reading hub. Data from the interview and questionnaire were triangulated with quantitative data collected via the MMSR feedback form. Descriptive statistic was used to firstly, summarise parents' motivation scores, and secondly to compile feedback to cross-refer to how parents' attitude and motivation were influenced by the quality of 
emergent literacy app and materials. It was also used to identify parents' level of participation in informal multilingual readings to children. The interview transcripts were analysed using QDA Miner lite version. Data gathered from questionnaire and feedback form was analysed using IBM SPSS.

\subsection{Materials}

MMSR was developed to serve as a conceptual test for an "unfettered learning" platform, where multilingual learning is "on the go - anywhere, anytime." It was designed for two purposes. First, to provide the children with greater exposure to multiple languages within the MALL framework. A total of 26 levelled eBooks was distributed weekly. This mode of delivery was aimed at gauging how parents and their children respond to new materials as well as at creating new stories that were of their reading preferences. As shown in Figure 3, stories in three languages were made available on the MMSR during parent-child shared book reading. It was aimed at developing the children's awareness of oral and written differences between these languages [32]. MMSR was designed as a basic eBook app that lacks interactive features to eliminate unnecessary cognitive load and avoid distraction; hotspots were limited to buttons that trigger audio presentations, no background music, and no games [21]. Each sentence has a dedicated play button which can be pressed to listen to a sentence. Each word can also be touched to listen to its pronunciation. Options of language choice and text size can be selected too (see Figure 4). A glossary page which presents new words that were deemed to be difficult for the children serves as a reference, i.e. similar to a dictionary that helps increase children's understanding of the texts was incorporated (see Figure 5).

Second, it serves as a hub within the MALL to link homes and the school in a joint effort to develop the children's early multilingual literacy skills. A feedback form (see Figure 6) contains three input data: (1) rating of a story which users are able to rate an eBook by selecting the number of stars from the default of no star (Very dissatisfied) to the maximum of five stars (Very satisfied), (2) a voice comment about each story, and (3) an indication of the children's reading partner: parents, sibling or others. Parents and children were encouraged to record their feedback for each reading session.

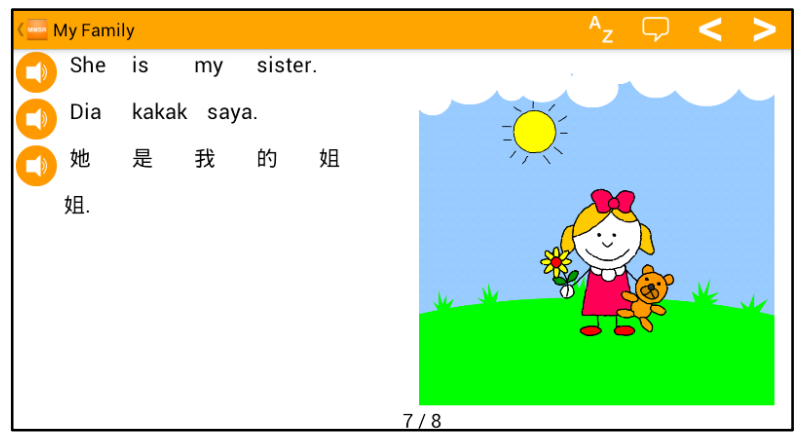

Fig. 3. Storybook in multiple languages 


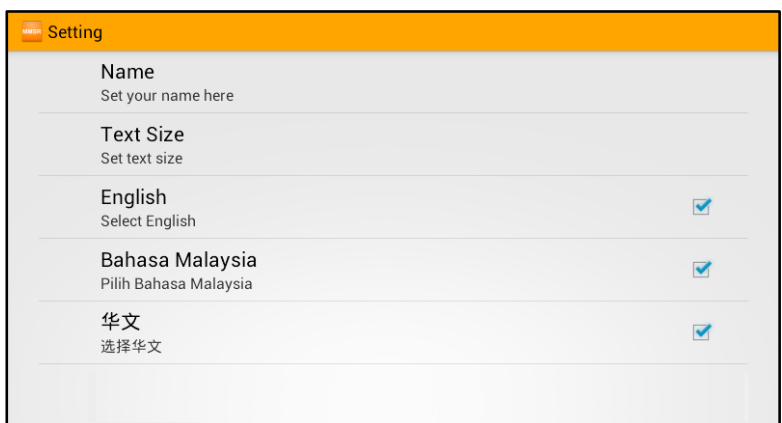

Fig. 4. Settings page

\begin{tabular}{|c|c|c|}
\hline \multicolumn{3}{|l|}{ Elossary } \\
\hline English & Bahasa Malaysia & 华文 \\
\hline Family & Keluarga & 家庭 Jiāting \\
\hline Grandfather & Datuk & 分分 Yéyé \\
\hline Grandmother & Nenek & 雬婆 Pópo \\
\hline Father & Bapa & 爸爸 Bàba \\
\hline Mother & Ibu & 妈妈 Māmā \\
\hline Brother & Abang & 哥哥 Gēgē \\
\hline Sister & Kakak & 姐姐 Jiějiě \\
\hline
\end{tabular}

Fig. 5. Glossary

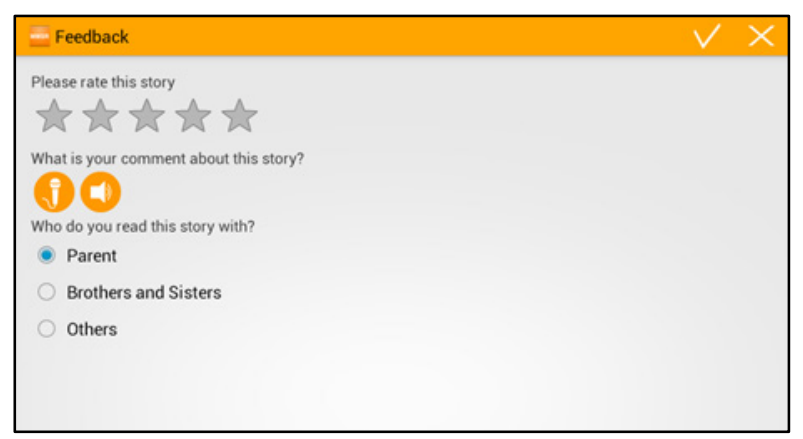

Fig. 6. Feedback form

\section{$5 \quad$ Results}

Descriptive statistics were used to measure frequency for all dependent variables. Subsequently, non-parametric tests were applied to determine statistically significant differences between parents of different academic levels and multilingual literacy skills. Non-parametric tests were used because the sample size was small $(n=25)$ and the data 
were ordinal variables. Parents' comments recorded during the interview were transcribed verbatim. Pseudonyms are used to conceal identity, i.e. Parent A refers to the parent of child A. Voice comments recorded on the MMSR by the parents using the feedback form was limited; only two comments were recorded and hence excluded. The results are presented in answer to the research questions.

\subsection{What are the parents' levels of acceptance of MALL?}

This study found that parents were positive towards MMSR as a multilingual learning tool. More than 80 per cent of the parents indicated they "Strongly Agree" and "Agree" for most of the items in the questionnaire (see Table 3). They were of the opinion that MMSR is useful in learning multiple languages, i.e. firstly, it provides children with more exposure to different languages in a multilingual learning environment; it makes learning multilingual easier, and secondly, it provides children with a learning space to read multiple languages in a mobile application environment. The results of a Kruskal-Wallis test found no difference in the attitude score between parents with different academic levels, $x^{2}(2)=.003, p=.968$. Results of Spearman correlation indicated that there was non-significant association between the parents' attitude scores and their self-assessed multilingual literacy skills scores, $p>.103$.

Table 3. Parents' attitude towards MMSR

\begin{tabular}{|c|c|c|c|c|c|}
\hline \multirow[t]{2}{*}{ Statement } & $\begin{array}{l}\text { Strongly } \\
\text { Agree }\end{array}$ & Agree & Neutral & Disagree & $\begin{array}{l}\text { Strongly } \\
\text { Disagree }\end{array}$ \\
\hline & No. (\%) & No. (\%) & No. (\%) & No. (\%) & No. (\%) \\
\hline $\begin{array}{l}\text { MMSR is a useful way to learn multi- } \\
\text { ple languages }\end{array}$ & $12(48.0)$ & 11(44.0) & $2(8.0)$ & $0(0.0)$ & $0(0.0)$ \\
\hline $\begin{array}{l}\text { MMSR provides children more expo- } \\
\text { sure to a multilingual learning environ- } \\
\text { ment }\end{array}$ & $15(60.0)$ & $8(32.0)$ & $2(8.0)$ & $0(0.0)$ & $0(0.0)$ \\
\hline $\begin{array}{l}\text { MMSR makes learning multiple lan- } \\
\text { guages easier }\end{array}$ & $14(56.0)$ & $10(40.0)$ & $1(4.0)$ & $0(0.0)$ & $0(0.0)$ \\
\hline $\begin{array}{l}\text { MMSR provides children a learning } \\
\text { space to read multiple languages any- } \\
\text { where, anytime }\end{array}$ & $15(60.0)$ & $8(32.0)$ & $2(8.0)$ & $0(0.0)$ & $0(0.0)$ \\
\hline
\end{tabular}
$(\mathrm{n}=25)$

As seen in Table 4, the majority of the parents were satisfied with the quality of eBooks; with approximately 70 per cent of feedback recorded a positive rating. A total of 289 feedback records (approximately 84\%) were submitted by parents, which also indicated a high level of parental involvement in their children's early reading development. Siblings and other adults were also reported to read to the children, but at a lower level of involvement (approximately 26\%) compared to their parents.

The frequency of feedback recorded on the eBooks is presented in Table 5 which shows that most of the parent-child reading sessions $(58.84 \%)$ recorded two or more feedback records. This is an indication that parents repeatedly read some eBooks to the children. On the other hand, approximately 41 per cent of the parent-child reading session resulted in at least one recorded feedback. The highest number of feedback recorded for a single eBook was 11 . Parents confirmed during the interview that some had 
repeatedly read to the children because they enjoyed the story. One of the parents commented that "since teacher installs this story he shows it to his sister. From that on, they open and read it together every day" (Parent R).

Table 4. Rating of eBook

\begin{tabular}{|c|c|c|c|c|c|c|}
\hline \multirow[t]{2}{*}{$\begin{array}{l}\text { Reading } \\
\text { Partners }\end{array}$} & $\begin{array}{l}\text { Very Sat- } \\
\text { isfied }\end{array}$ & Satisfied & Moderate & $\begin{array}{c}\text { Dissatis- } \\
\text { fied }\end{array}$ & $\begin{array}{c}\text { Very Dissat- } \\
\text { isfied }\end{array}$ & \multirow[t]{2}{*}{ Total } \\
\hline & No. (\%) & No. (\%) & No. (\%) & No. (\%) & No. (\%) & \\
\hline Parents & $95(32.9)$ & $102(35.3)$ & $61(21.1)$ & $17(5.9)$ & $14(4.8)$ & $289(83.8)$ \\
\hline Siblings & $28(59.6)$ & $7(14.9)$ & $12(25.5)$ & $0(0.0)$ & $0(0.0)$ & $47(13.6)$ \\
\hline Others & $7(77.8)$ & $1(11.1)$ & $0(0.0)$ & $0(0.0)$ & $1(11.1)$ & $9(2.6)$ \\
\hline Total $(\%)$ & $130(37.7)$ & $110(31.9)$ & $73(21.2)$ & $17(4.9)$ & $15(4.3)$ & $345(100.0)$ \\
\hline
\end{tabular}

Table 5. Frequency of feedback on eBook

\begin{tabular}{|l|l|}
\hline \multicolumn{1}{|c|}{ Frequency of feedback } & \multicolumn{1}{c|}{ No. (\%) } \\
\hline At least once & $142(41.16)$ \\
\hline Two feedback records and above & $203(58.84)$ \\
\hline Total & $345(100.00)$ \\
\hline
\end{tabular}

When parents were also asked to identify the MMSR's features that they liked and disliked, four distinctive features were highlighted, i.e. multilingual, multimedia, contents, and mobile device. Some of the parent's comments were presented in Table 6. Majority of parents were of the opinion that having multiple languages in a single eBook was a right design for the MMSR. Some parents also maintained that having multiple languages enabled them to help their children to identify differences between the three languages (see comment 2). However, one of the parents perceived that multilingual features are confusing and believed that languages should be introduced to children separately (see comment 3 ).

Parents appreciated the MMSR multimedia features that helped the children to maintain focus and enhanced their story comprehension (see comment 4). Many parents indicated that the MMSR multimedia presentation assisted their children to progress through stories easily and helped them recognise new words in other languages. Parents also commented that they liked the MMSR ability to utter sentences and words (see comment 5). However, a small group of parents commented that words pronounced by the text-to-speech (TTS) engine were not natural, incorrect, or too fast (see comments 6 to 8$)$.

Majority of parents felt that MMSR makes the learning of multiple languages easier because the contents of eBook matched their children's reading ability (see comment 9). One of the parents highlighted that the way eBooks were introduced to the children according to their reading levels was appropriate (see comment 10). However, two parents commented that the eBooks could be further enhanced by adding advanced multimedia features and various genres (see comments 11 and 12).

Parents in this study also had developed an awareness of the educational value of tablets. They perceived tablet as a potential learning tool to enhance children's learning (see comment 13). A parent had also noted that her child has gained better knowledge of a tablet, i.e. techno-literacy and referred it over the conventional approach. In general, being mobile, most parents perceived MMSR positively as a tool that caters to 
children learning sphere for multiple languages reading anywhere, anytime (see comment 14). However, a parent expressed disfavour for eBook reading due to health concerns (see comment 15).

Table 6. Parents' comments on MALL

\begin{tabular}{|c|c|c|}
\hline Features & Favourable Comments & Unfavourable Comments \\
\hline Multilingual & $\begin{array}{l}\text { 1. The thing I love most is that it } \\
\text { has three languages. (Parent P) } \\
\text { There are English and Malay. } \\
\text { For example, the word 'bus'. } \\
\text { In English, it is spelt "BUS". } \\
\text { In Malay, it is 'BAS', they are } \\
\text { spelt differently (Parent Z) }\end{array}$ & $\begin{array}{l}\text { 3. You do not have to } \\
\text { show all languages; it } \\
\text { is confusing to chil- } \\
\text { dren. It is better to } \\
\text { show them one lan- } \\
\text { guage at a time. (Par- } \\
\text { ent J) }\end{array}$ \\
\hline Multimedia & $\begin{array}{l}\text { 4. Children can be more focus. } \\
\text { They see the picture, they learn } \\
\text { very fast because if only audio } \\
\text { is not enough for them. They } \\
\text { see a picture and they remem- } \\
\text { ber. (Parent M) } \\
\text { The sentence in a story is long, } \\
\text { but once the play button is } \\
\text { pressed, the tablet can read the } \\
\text { sentence. It does not only read } \\
\text { sentences, but it can also read } \\
\text { each word, this is good. } \\
\text { (Parent T) }\end{array}$ & 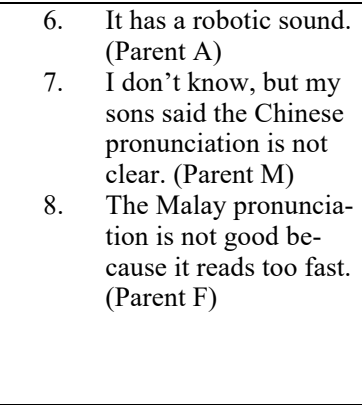 \\
\hline Contents & $\begin{array}{l}\text { 9. It is good for children because } \\
\text { they are all basic. (Parent Y) } \\
\text { 10. The program is good. The way } \\
\text { how you tabulating it from } \\
\text { time to time you upgrade [dif- } \\
\text { ferent levels of stories] and } \\
\text { you show them. (Parent E) }\end{array}$ & $\begin{array}{l}\text { 11. Make the story inter- } \\
\text { esting for them. They } \\
\text { like games or some- } \\
\text { thing similar. (Parent } \\
\text { O) } \\
\text { 12. Too easy for him. He } \\
\text { likes to learn more } \\
\text { (Parent E) }\end{array}$ \\
\hline Device & $\begin{array}{l}\text { 13. If we ask them anything about } \\
\text { this tablet, they can tell us eve- } \\
\text { rything about it....children pre- } \\
\text { fer the tablet than chalk and } \\
\text { talk (Parent T) } \\
\text { 14. It provides more time to learn } \\
\text { more no matter where they are } \\
\text { and any time they want my son } \\
\text { can read storybook while trav- } \\
\text { elling (Parent P) }\end{array}$ & $\begin{array}{l}\text { When they look at this } \\
\text { tablet their eyes go to } \\
\text { the centre [eyes misa- } \\
\text { ligned]. I really cannot } \\
\text { accept it. I prefer them } \\
\text { to read text on paper. } \\
\text { (Parent } \mathrm{J} \text { ) }\end{array}$ \\
\hline
\end{tabular}

\subsection{To what extent does the MALL affect the parents' attitude and motivation towards reading to children in multiple languages?}

To gather data in answering the second research question, parents were asked to selfevaluate the effects of MMSR on their attitude towards reading multilingual eBooks to their children. As shown in Table 7, the majority of parents maintained that MMSR motivated them to read multilingual eBooks to their children and had a positive impact on their attitude and motivation towards reading multilingual eBooks to their children. Only a small number of parents, however, disagreed that MMSR had a positive effect 
on their motivation to read multilingual eBooks to their children. The Kruskal-Wallis test found non-statistically significant difference between the parents' motivation score and their education levels, $x^{2}(2)=.020, p=.893$. The Spearman correlation between the parents' motivation scores and their self-assessed multilingual literacy skills scores were found to be statistically non-significant, $p>.198$.

Table 7. Parents' attitude and motivation towards reading multilingual eBooks to their children

\begin{tabular}{|l|c|c|c|c|c|}
\hline \multicolumn{1}{|c|}{ Statement } & $\begin{array}{c}\text { Strongly } \\
\text { Agree }\end{array}$ & Agree & $\begin{array}{c}\text { Neu- } \\
\text { tral }\end{array}$ & $\begin{array}{c}\text { Disa- } \\
\text { gree }\end{array}$ & $\begin{array}{c}\text { Strongly } \\
\text { Disagree }\end{array}$ \\
\cline { 2 - 6 } & No (\%) & No (\%) & No (\%) & No (\%) & No (\%) \\
\hline $\begin{array}{l}\text { MMSR has motivated me to read Eng- } \\
\text { lish, Malay, and Chinese storybooks to } \\
\text { my child }\end{array}$ & $12(48.0)$ & $6(24.0)$ & $6(24.0)$ & $1(4.0)$ & $0(0.0)$ \\
\hline $\begin{array}{l}\text { MMSR has a positive impact on my atti- } \\
\text { tude and motivation toward reading mul- } \\
\text { tilingual storybooks to my child }\end{array}$ & $12(48.0)$ & $11(44.0)$ & $2(8.0)$ & $0(0.0)$ & $0(0.0)$ \\
\hline
\end{tabular}
$(\mathrm{n}=25)$

Parents were also asked to self-evaluate changes in their attitude and motivation towards reading multilingual eBooks to their children. Their comments are presented in table 8 . The majority of parents commented that they had developed a positive attitude and motivation towards reading multilingual eBooks to their children because the MMSR's multilingual feature helped them understand a story easily and enabled them to transfer knowledge from their first language to another (see comment 1). Some parents also developed the interest in learning a second language (see comment 2 and 3). However, three parents commented that their preferred reading language is their mother tongue and not the others (see comment 4 ). Another noticeable change observed by parents was that the MALL encouraged them to read to their children (see comment 5). Some parents were of the opinion that the MALL provided opportunities for the adultchild shared reading session and had brought the whole family to read together (see comment 6). However, three parents noted that they were not motivated to read to their children (see comment 7). Some parents attributed that their positive attitude was the result of their children's positive motivation. One of them commented that his son was motivated to read eBooks using MMSR and looked forward to getting new eBooks every Friday (see comment 8). Two parents acknowledged their children's lack of motivation towards reading and preferred alternative learning media (see comment 9 and 10). A parent believed that MMSR, in a tablet form, had a positive impact on her child's reading skills (see comment 11). However, another parent believed that her child enjoyed printed books compared to eBooks (see comment 12).

Table 8. Parents' attitude towards MALL

\begin{tabular}{|l|ll|c|}
\hline \multicolumn{1}{|c|}{ Themes } & Positive Attitude & \multicolumn{2}{c|}{ Negative Attitude } \\
\hline $\begin{array}{l}\text { Multilingual } \\
\text { Reading }\end{array}$ & 1. & $\begin{array}{l}\text { I read the Chinese texts to un- } \\
\text { derstand the Malay. (Parent W) }\end{array}$ & $\begin{array}{l}\text { No change of my } \\
\text { attitude. I only } \\
\text { read in Tamil. } \\
\text { (Parent V) }\end{array}$ \\
\hline
\end{tabular}




\begin{tabular}{|c|c|c|c|c|}
\hline & $\begin{array}{l}2 . \\
3 .\end{array}$ & $\begin{array}{l}\text { I do not know how to speak } \\
\text { Chinese. I also can check it out. } \\
\text { (Parent E) } \\
\text { I also learn a lot from the tablet. } \\
\text { (Parent M) }\end{array}$ & & \\
\hline $\begin{array}{l}\text { Adult-child inter- } \\
\text { action }\end{array}$ & 5. & $\begin{array}{l}\text { They will be more interested } \\
\text { (in reading) if I read to them } \\
\text { because they get to understand } \\
\text { the story more. (Parent A) } \\
\text { We read together. The first day } \\
\text { we brought back the tablet } \\
\text { home we sat together and see } \\
\text { what you offer from the tablet. } \\
\text { (Parent R) }\end{array}$ & & $\begin{array}{l}\text { Only my daugh- } \\
\text { ter reads the sto- } \\
\text { ries, I don't read. } \\
\text { (Parent D) }\end{array}$ \\
\hline $\begin{array}{l}\text { Children's moti- } \\
\text { vation }\end{array}$ & & $\begin{array}{l}\text { He would show me new story- } \\
\text { book every Friday. He would } \\
\text { remind me to bring the tablet to } \\
\text { school. (Parent W). }\end{array}$ & 9. & $\begin{array}{l}\text { She prefers to } \\
\text { watch YouTube. } \\
\text { (Parent A) } \\
\text { He likes singing. } \\
\text { He doesn't like } \\
\text { reading stories. } \\
\text { (Parent N) }\end{array}$ \\
\hline $\begin{array}{l}\text { Positive percep- } \\
\text { tion toward tablet }\end{array}$ & & $\begin{array}{l}\text { After using tablet, she has im- } \\
\text { proved a lot in her reading } \\
\text { skills. (Parent L) }\end{array}$ & 12. & $\begin{array}{l}\text { They prefer } \\
\text { [printed] story- } \\
\text { book. (Parent } \mathrm{J} \text { ) }\end{array}$ \\
\hline
\end{tabular}

\section{Discussion}

This study proposed a MALL framework, where a school and homes work together to scaffold children's early emergent multilingual literacy skills development. Prior research has indicated that children acceptance of mobile learning is high [13] [14], however, parents prefer their children to read printed books over eBooks [4] [12]. This study thus provides evidence for the application of the MALL framework to create parents' positive attitude toward reading multilingual eBooks to young children in developing early emergent multilingual literacy.

A high level of acceptance of digital print reading among parents regardless of their education levels and multilingual literacy skills, which is consistent with the findings of Radesky, Schumacher, and Zuckerman [15] is evident. Similar to the findings of Ozdamli and Yildiz [13], parents also acknowledged that they developed positive attitudes towards mobile devices and the value of MALL in the context of multilingual learning. One obvious evidence recorded in the MMSR was that parents repeatedly read eBooks with their children.

Multimedia and multilingual were two essential features that appeared to motivate parents to use the MMSR. Consistent with Clark and Mayer's [18] findings, the multimedia presentation in the MMSR motivated parents to read the eBooks to the children because it helped them to form links between the media and assisted them to navigate through difficult texts. As parents reported, the multilingual text presentation had helped to develop their children's awareness of the oral and written differences between the three languages and reading eBooks that contain the children's first language supported the literacy development of their second language, which is consistent to the findings of Kabuto [32]. 
However, there were also parents who responded to MALL unfavourably, citing various reasons, including children's lack of motivation to read and lack of self-motivation to read in second languages. Consistent with Radesky, Schumacher, and Zuckerman's [15] findings, parents were also concerned with the children prolong screen time. In addition, a parent believed that her children enjoyed printed book more than eBooks as reported by Gabrielle and Patricia [12].

\section{Conclusion}

It is important to understand home reading behaviours for MALL to be an effective model to develop early emergent multilingual literacy skills. Although the statistical data on informal reading obtained from the MMSR helped the school to create a profile of each participating family, the reasons for their favourable or unfavourable attitude and motivation towards reading each eBook remain unclear as most parents were found to be reluctant to provide voice comments, using the feedback form. To encourage more school-home information exchange, communication features of mobile devices, such as instant messaging, voice and video call, could be incorporated to serve the purpose.

This study was conducted within a limited timeframe, participant, and resources to identify the effects of MALL on parents' attitude and motivation towards reading multilingual storybooks to their children. Thus, it is not able to determine the longitudinal effects of MALL on parents' attitude towards reading multilingual eBooks to their children. Future research may include more participants, conduct the study over a longer duration, add more eBooks, and expand support for more languages. Another area of research is to identify the children's attitude towards reading multilingual eBooks using mobile devices.

Evidence has shown that the MALL framework, where educators and parents create a shared meaningful learning environment to develop children's early emergent multilingual literacy, using tablets installed with multilingual eBooks is feasible. This study found that multilingual texts and multimedia features of eBooks motivated parents to scaffold their children's emergent multilingual literacy skills development. These findings point to use of the MMSR as a springboard for educators and parents to consider adopting to collaborate in developing early multilingual literacy in a multilingual context. It is possible to develop multiple languages simultaneously using the MMRS.

\section{References}

[1] E. Reese, A. Sparks and D. Leyva, "A review of parent interventions for preschool children's language and emergent literacy," Journal of Early Childhood Literacy, 10(1), pp. 97-117, 2010. https://doi.org/10.1177/1468798409356987

[2] M. Bava Harji, K. Balakrishnan and K. Letchumanan, "SPIRE Project: Parental Involvement in Young Children's ESL Reading Development," English Language Teaching, 9(12), pp. 1-15, 2016. https://doi.org/10.5539/elt.v9n12p1 
[3] G. J. Hwang and P. H. Wu, "Applications, impacts and trends of mobile technology-enhanced learning: a review of 2008-2012 publications in selected SSCI journals," International Journal of Mobile Learning and Organisation, 8(2), pp. 83-95, 2014.

[4] S. Maynard, "The impact of e-books on young children's reading habits," Publishing Research Quarterly, 26(4), pp. 236-248, 2010. https://doi.org/10.1007/s12109-010-9180-5

[5] C. M. Hall and K. L. Bierman, "Technology-assisted interventions for parents of young children: Emerging practices, current research, and future directions," Early Childhood Research Quarterly, 33, pp. 21-32, 2015. https://doi.org/10.1016/j.ecresq.2015.05.003

[6] N. Kucirkova, D. Messer, K. Sheehy and R. Flewitt, "Sharing personalised stories on iPads: A close look at one parent-child interaction," Literacy, 47(3), pp. 115-122, 2013. https://doi.org/10.1111/lit.12003

[7] M. M. Neumann and D. L. Neumann, "The use of touch-screen tablets at home and preschool to foster emergent literacy," Journal of Early Childhood Literacy, pp. 1-18, 2015.

[8] S. S. Sim, D. Berthelsen, S. Walker, J. M. Nicholson and R. Fielding-Barnsley, "A shared reading intervention with parents to enhance young children's early literacy skills," Early child development and care, 184(11), pp. 1531-1549, 2014. https://doi.org/10.1080/0300 $\underline{4430.2013 .862532}$

[9] M. Huennekens and Y. Xu, "Effects of a cross-linguistic storybook intervention on the second language development of two preschool English language learners," Early Childhood Education Journal, 38(1), pp. 19-26, 2010. https://doi.org/10.1007/s10643-010-0385-1

[10] S. Huang, "The use of literacy bags promotes parental involvement in Chinese children's literacy learning in the English language," Language Teaching Research, 17(2), pp. 251268, 2013. https://doi.org/10.1177/1362168813475950

[11] M. Bava Harji, ELS Literacy Development and Story Reading: Implementation and Evaluation of a SMART Partnership (Unpublished doctoral dissertation), Multimedia University, Malaysia, 2002.

[12] A. S. Gabrielle and A. G. Patricia, "A print book preference: Caregivers report higher child enjoyment and more adult-child interactions when reading print than electronic books, " International Journal of Child-Computer Interaction, vol. 12, pp. 8-15, 2017. https://doi.org/10.1016/j.ijcci.2017.02.001

[13] F. Ozdamli and P. Yildiz, "Opinions and Expectations of Parents on Integration of Mobile Technologies to Education and School Family Cooperation," International Journal of Interactive Mobile Technologies, vol. 11, no. 4, pp. 136-148, 2017. https://doi.org/10.3991 /ijim.v11i4.6791

[14] I. Picton, "The Impact of eBooks on the Reading Motivation and Reading Skills of Children and Young People: A Rapid Literature Review," National Literacy Trust, 2014.

[15] J. S. Radesky, J. Schumacher and B. Zuckerman, "Mobile and interactive media use by young children: the good, the bad, and the unknown," Pediatrics, 135(1), pp. 1-3, 2015. https://doi.org/10.1542/peds.2014-2251

[16] R. E. Mayer, "Cognitive theory of multimedia learning," in The Cambridge handbook of multimedia learning, New York, Cambridge University Press, 2014, p. 43. https://doi.org/10.1017/CBO9781139547369.005

[17] K. Ciampa, "Reading in the Digital Age: Using Electronic Books as a Teaching Tool for Beginning Readers," Canadian Journal of Learning and Technology, 38(2), pp. 1-26, 2012.

[18] R. C. Clark and R. E. Mayer, E-learning and the science of instruction: Proven guidelines for consumers and designers of multimedia learning, John Wiley \& Sons, 2011. https://doi.org/10.1002/9781118255971 
[19] A. G. Bus, Z. K. Takacs and C. A. T. Kegel, "Affordances and limitations of electronic storybooks for young children's emergent literacy," Developmental Review, vol. 35, pp. 7997, 2015. https://doi.org/10.1016/j.dr.2014.12.004

[20] C. Chiong, J. Ree, L. Takeuchi and I. Erickson, "Comparing Parent-Child Co-Reading on Print, Basic, and Enhanced E-Book Platforms: A Cooney Center Qui ckreport," 20 May 2012. [Online]. Available: http://www.joanganzcooneycenter.org/wpcontent/uploads/2012/07/jgcc_ebooks_quickreport.pdf.

[21] M. Krcmar and D. P. Cingel, "Parent-child joint reading in traditional and electronic formats," Media Psychology, 17(3), pp. 262-281, 2014. https://doi.org/10.1080/ $\underline{15213269.2013 .840243}$

[22] D. Willoughby, M. A. Evans and S. Nowak, "Do ABC eBooks boost engagement and learning in preschoolers? An experimental study comparing eBooks with paper ABC and storybook controls," Computers \& Education, 82, pp. 107-117, 2015. https://doi.org/10.101 6/j.compedu.2014.11.008

[23] A. J. L. \&. C. S. Moody, "Electronic versus traditional storybooks: Relative influence on preschool children's engagement and communication," Journal of Early Childhood Literacy, 10(3), pp. 294-313, 2010. https://doi.org/10.1177/1468798410372162

[24] A. Richter and M. L. Courage, "Comparing electronic and paper storybooks for preschoolers: Attention, engagement, and recall," Journal of Applied Developmental Psychology, 48, pp. 92-102, 2017. https://doi.org/10.1016/j.appdev.2017.01.002

[25] L. H. Wong and C. K. Looi, "Mobile-Assisted Vocabulary Learning in Real-Life Setting for Primary School Students: Two Case Studies," 2010 6th IEEE International Conference on Wireless, Mobile, and Ubiquitous Technologies in Education, pp. 88-95, 2010.

[26] W. Y. Hwang and H. S. L. Chen, "Users' familiar situational contexts facilitate the practice of EFL in elementary schools with mobile devices," Computer Assisted Language Learning, 26 (2), pp. 101 - 125, 2013. https://doi.org/10.1080/09588221.2011.639783

[27] F. Ihmeideh, "The effect of electronic books on enhancing emergent literacy skills of preschool children," Computers \& Education, 79, pp. 40-48, 2014. https://doi.org/10.1016/j.co mpedu.2014.07.008

[28] S. Judge, K. Floyd and T. Jeffs, "Using mobile media devices and apps to promote young children's learning," in Young Children and Families in the Information Age, Educating the Young Child, Springer, 2015, pp. 117-131.

[29] L. Vygotsky, Mind in Society: The Development of Higher Psychological Processes, Cambridge, MA: Harvard University Press, 1978.

[30] D. Robbins, Vygotsky's psychology-philosophy: A metaphor for language theory and learning, New York: Springer Science \& Business Media, 2001. https://doi.org/10.1007/978-14615-1293-6

[31] D. Wood, J. S. Bruner and G. Ross, "The role of tutoring in problem solving," Journal of Child Psychology and Psychiatry, 17(2), pp. 89-100, 1976. https://doi.org/10.1111/j.14697610.1976.tb00381.x

[32] B. Kabuto, "Code-switching during parent—child reading interactions: Taking multiple theoretical perspectives," Journal of Early Childhood Literacy, 10(2), pp. 131-157, 2010. https://doi.org/10.1177/1468798409345109

[33] S. M. Reich, J. C. Yau and M. Warschauer, "Tablet-Based eBooks for Young Children: What Does the Research Say?," Journal of Developmental \& Behavioral Pediatrics, vol. 37 , no. 3, p. 585-591, 2016. 


\section{$9 \quad$ Authors}

Kwee Teck See is a lecturer in the Department of Information and Communication Technologies at the Tunku Abdul Rahman University College, Malaysia.

Bava Harji Madhubala currently works at the Faculty of Applied Communication, at the Multimedia University. Madhubala does research in Pre-school Education, Teaching Methods and Educational Technology.

Ah Choo Koo has done her PHD and is a member staff in the Faculty of Creative Multimedia at Multimedia University.

Article submitted 15 June 2018. Resubmitted 16 October 2018. Final acceptance 22 November 2018. Final version published as submitted by the authors. 